\title{
JUMLAH, JENIS, FREKUENSI KONSUMSI MAKANAN, DAN STATUS GIZI ANAK BALITA DI KELURAHAN BELAWAN II
}

\author{
Frans Judea Samosir*, Yessy Firstiana \\ Fakultas Kesehatan Masyarakat Universitas Prima Indonesia \\ email: frans_judea@yahoo.com
}

\begin{abstract}
ABSTRAK
Kecenderungan prevalensi status gizi anak balita di Indonesia adalah meningkat dari tahun 2007 ke tahun 2013 yaitu status gizi buruk 5,4\% (2007) menjadi 5,7\% (2013) sedangkan gizi kurang 13,0 (2007) menjadi 13,9\% (2013). Di Kelurahan Belawan II Kecamatan Medan Belawan terdapat 1060 anak balita, diantaranya dua anak balita mengalami status gizi buruk (2016). Penelitian ini bertujuan untuk mengetahui hubungan jumlah, jenis dan frekuensi konsumsi makanan dengan status gizi anak balita di Kelurahan Belawan II Kecamatan Medan Belawan. Jenis penelitian adalah survai analitik dengan rancangan cross sectional. Populasi penelitian terdiri dari 1060 anak balita, sampel terdiri dari 53 anak balita dan responden 53 orang ibu. Pengumpulan data jumlah, jenis dan frekuensi konsumsi makanan menggunakan Metode Food Recall 24 jam selama dua hari tidak berturut-turut dan status gizi menggunakan Antropometri dengan indeks Berat Badan menurut Umur (BB/U). Analisis data dilakukan dengan uji chi-square. Diperoleh data, 98.1 persen jumlah konsumsi makanan sampel berkategori baik, 96.2 persen jenis konsumsi makanan tidak beragam, 100 persen sampel frekuensi konsumsi makannya tidak sering, sehingga pola konsumsi makanan sampel seluruhnya tidak baik. Sampel berstatus gizi baik 62,3 persen, gizi kurang 35,8 persen, dan 1,9 persen berstatus gizi kategori buruk. Hasil analisis statistik menyatakan tidak ada hubungan jumlah konsumsi makanan dengan status gizi anak balita, juga jenis konsumsi makanan dengan status gizi anak balita tetapi ada hubungan frekuensi konsumsi makanan dengan status gizi anak balita. Disarankan kepada ibu dari anak balita di Kelurahan Belawan II Kecamatan Medan Belawan agar diberi bekal pengetahuan dan keterampilan seputar gizi anak balita di Posyandu.
\end{abstract}

Kata kunci: Konsumsi makanan, status gizi, balita

\begin{abstract}
The tendency of the prevalence of nutritional status of balita (below five year-old children) in Indonesia increased from 2007 to 2013: the status of malnutrition was from 5.4\% in 2007 to 5.7\% in 2013. Of the 1060 below five year-old children at Kelurahan Belawan II in 2016, two of them suffered from malnutrition. The objective of the research was to find out the correlation between the amount of food consumption, type of food consumption and frequency of food consumption with the nutritional status of below five year-old children at Kelurahan Belawan II, Medan Belawan. The research used an analytic survey method with sectional design. The population was 1060 below five year-old children, and 53 of them were used as the samples and the respondents consisted of 53 mothers. The data of food consumption pattern were gathered by using a 24 Hour-Food Recall, and the nutritional status anthropometry with BB/U (Body Weight of Age). The data were analyzed by using chi-square test. The result showed that $98.1 \%$ of the samples of food consumption pattern were in good category, 96.2\% of the type of food consumption was not varied, $100 \%$ of the samples of food consumption frequency was infrequent, so that all in all the samples of food consumption was not good. $62.3 \%$ of the samples were good nutritional status, $35.8 \%$ the samples were nutritional deficiency, and $1.9 \%$ of the samples were malnutrition. The result of the statistic analysis showed that there was no correlation of the amount of food consumption with the nutritional status of balita and the type of food consumption with the nutritional status of balita. There was correlation between the frequency of food consumption and the nutritional status of below balita. It is recommended that the mothers who have balita be provided with knowledge and skill on child nutrition in Posyandu (Integrated Health Service Post).
\end{abstract}

Keywords: Food consumption, nutritional status, balita 


\section{LATAR BELAKANG}

Pola konsumsi makanan merupakan gambaran mengenai jumlah, jenis dan frekuensi bahan makanan yang dikonsumsi seseorang sehari-hari dan merupakan ciri khas pada satu kelompok masyarakat tertentu.(1) Pola konsumsi makanan yang keliru menempatkan anak balita dalam posisi rentan masalah gizi. Oleh karena itu adanya masalah makanan jika tidak diperhatikan oleh orang tua akan memengaruhi pemenuhan gizi dan status gizi anak. Pola makan atau kebiasaan makan yang keliru menempatkan balita dalam posisi rentan masalah gizi. Selama masa balita pula, kebanyakan anak hanya mau makan satu jenis makanan selama berminggu-minggu. Oleh karena itu adanya masalah makanan tersebut jika tidak diperhatikan oleh orang tua akan mempengaruhi pemenuhan gizi dan status gizi anak. (2)

Menurut hasil penelitian (3) di Tompaso, $22 \%$ dari 150 anak balita dengan pola makan tidak baik. Sedangkan penelitian (4) di Kabunan Taman Pemalang menemukan 45,5\% dari 33 anak balita pola makannya tidak baik. Pola makan tidak baik, secara langsung berdampak negatif terhadap status gizi. Status gizi adalah ekspresi keadaan keseimbangan dalam bentuk variabel tertentu, atau perwujudan dari nutriture dalam bentuk variabel tertentu.(5) Kecenderungan prevalensi status gizi anak balita menurut berat badan menurut umur, prevalensi gizi buruk dan gizi kurang meningkat dari tahun 2007 ke tahun 2013 yaitu gizi buruk $5,4 \%$ pada tahun 2007 dan 5,7\% pada tahun 2013 sedangkan gizi kurang $13,0 \%$ pada tahun 2007, dan $13,9 \%$ pada tahun 2013. (Balitbang Kemenkes RI, 2013). Berdasarkan hasil (6) bahwa prevalensi gizi buruk di Indonesia sebesar $5,7 \%$ dan gizi kurang sebesar $13,9 \%$ dan prevalensi gizi buruk dan gizi kurang tertinggi yaitu Provinsi Sumatera Utara dengan prevalensi gizi buruk dan gizi kurang sebesar $21,4 \%$.

Hasil penelitian (3) membuktikan terdapat hubungan pola makan dengan status gizi pada anak balita diperoleh $12 \%$ dari 150 responden mempunyai pola makan tidak baik dengan status gizi kurang. Berdasarkan data (7), diketahui bahwa terdapat $2,74 \%$ balita dengan status gizi kurang dan $0,12 \%$ menderita gizi buruk dari 117.727 balita yang ditimbang pada tahun 2010 . Puskesmas Medan Belawan menduduki urutan nomor empat dengan status gizi kurang terbanyak yang berjumlah $3,10 \%$. Sementara berdasarkan hasil studi (8) di Puskesmas Medan
Belawan tahun 2012 memiliki 150 balita gizi kurang. Dibandingkan tahun 2010, persentasi balita gizi kurang tidak mengalami penurunan. Angka ini menunjukkan bahwa jumlah balita yang memiliki status gizi kurang cukup tinggi.

Hasil survei pendahuluan yang dilakukan di Puskesmas Belawan Kecamatan Medan Belawan pada Bulan Januari 2016 tercatat jumlah anak balita dengan status gizi kurang sebanyak 98 orang dan 5 orang dengan status gizi buruk dari 5483 orang. Pada Bulan Januari 2016 di Kelurahan Belawan II tercatat 1060 anak balita, terdapat masalah kumulatif kasus gizi buruk sebanyak 2 orang, hasil penimbangan berat badan tidak naik sebanyak $2,1 \%$ dan $1,1 \%$ anak balita berada dibawah garis merah (BGM).

Berdasarkan latar belakang hubungan pola konsumsi makanan dengan status gizi anak balita, peneliti tertarik untuk melakukan penelitian di Kelurahan Belawan II Kecamatan Medan Belawan yang merupakan daerah dengan jumlah gizi kurang yang tinggi di kota Medan menurut laporan Dinas Kesehatan Kota Medan pada Bulan Januari 2016.

\section{BAHAN DAN METODE}

Jenis penelitian yang digunakan adalah survai analitik dengan menggunakan rancangan cross sectional. Penelitian dilakukan di Kelurahan Belawan II Kecamatan Medan Belawan. Sampel dipilih dengan menggunakan teknik cluster sampling. Cara mengambil sampel dengan visit home to home (mengunjungi rumah ke rumah) untuk wawancara dan pengukuran konsumsi makanan menggunakan formulir food recall 24 jam selama dua hari tidak berturutturut.

Analisis univariat dilakukan terhadap masing-masing variabel baik variabel independen (jumlah, jenis dan frekuensi konsumsi makanan sampel) maupun terhadap variabel dependen (status gizi sampel) yang disajikan dalam bentuk tabel distribusi frekuensi.

Analisis bivariat adalah penyajian data dalam bentuk tabulasi silang, kemudian diuji secara statistik untuk membuktikan hubungan jumlah, jenis dan frekuensi konsumsi makanan dengan status gizi anak balita. Uji statistik yang digunakan adalah chi-square dengan derajat kemaknaan $(\alpha) 0,05$. Jika $P$ value $>0,05$ maka Ho diterima yang berarti tidak terdapat hubungan antara pola konsumsi makanan dengan status gizi anak balita, jika $\mathrm{P}$ value < 0,05 maka Ho ditolak yang berarti ada hubungan pola konsumsi makanan dengan status gizi anak balita. 
HASIL

Tabel 1. Distribusi Frekuensi Jumlah Konsumsi Makanan, Jenis Konsumsi Makanan, Frekuensi Konsumsi Makanan dana Status Gizi di Kelurahan Belawan II Kecamatan Medan Belawan

\begin{tabular}{lcc}
\hline \multicolumn{1}{c}{ Jumlah Konsumsi Makanan } & Jumlah & $\%$ \\
\hline $\begin{array}{l}\text { Baik } \\
\text { Kurang } \\
\text { Jenis Konsumsi Makanan }\end{array}$ & 52 & 98,1 \\
Beragam & 1 & 1,9 \\
Tidak Beragam & 2 & 3,8 \\
Frekuensi Konsumsi Makanan & 51 & 96,2 \\
Sering & & 0,0 \\
Tidak Sering & 0 & 100 \\
Status Gizi & 53 & 62,3 \\
Gizi Baik & & 35,8 \\
Gizi Kurang & 33 & 1,9 \\
Gizi Buruk & 19 & 100 \\
\hline
\end{tabular}

Sumber: (Data Primer, 2016)

\section{PEMBAHASAN}

Hubungan Jumlah Konsumsi Makanan dengan Status Gizi Sampel di Kelurahan Belawan II Kecamatan Medan Belawan

Berdasarkan uji chi-square diperoleh $p$ Value $=0,734(p$ value $>0,05)$ dan $\alpha=0,05$, maka Ho diterima sehingga tidak ada hubungan jumlah konsumsi makanan dengan status gizi sampel di Kelurahan Belawan II Kecamatan Medan Belawan. Menurut asumsi peneliti jumlah konsumsi makanan yang masuk ke dalam tubuh seseorang harus sesuai dengan jumlah konsumsi makanan yang dikeluarkan dan pemilihan makanan yang tepat dan sehat serta aktivitas yang seimbang untuk memperoleh status gizi baik.

Hubungan Jenis Konsumsi Makanan dengan Status Gizi Sampel di Kelurahan Belawan II Kecamatan Medan Belawan

Ada 51 orang sampel yang memiliki jenis konsumsi makanan tidak beragam. Berdasarkan uji chi-square diperoleh nilai $\mathrm{p}$ Value $=0,533(\mathrm{p}$ value $>0,05$ ) dan $\alpha=0,05$, maka Ho diterima sehingga tidak ada hubungan jenis konsumsi makanan dengan status gizi sampel di Kelurahan Belawan II Kecamatan Medan Belawan. Mayoritas mengalami status gizi baik yaitu sebanyak 31 orang $(58,5 \%)$. Hal ini disebabkan karena walaupun jenis konsumsi makanan tidak beragam namun jika jumlah makanan sesuai dengan kebutuhan kalori dan frekuensi konsumsi makanan sering, maka status gizi baik dapat diperoleh, namun kekurangan salah satu sumber zat gizi dapat menimbulkan masalah gizi, untuk itu sampel harus memenuhi sumber karbohidat, protein, lemak, vitamin dan mineral, sehingga asupan gizi dalam tubuh dapat terpenuhi dengan baik. Menurut asumsi peneliti jenis konsumsi makanan tidak berdampak langsung dengan status gizi, jenis konsumsi makanan beragam maupun tidak beragam apabila pemilihan makanan tidak tepat, tidak sehat dan jumlah berlebihan juga akan menimbulkan masalah status gizi.

Hubungan Frekuensi Konsumsi Makanan dengan Status Gizi Sampel di Kelurahan Belawan II Kecamatan Medan Belawan

Berdasarkan uji chi-square diperoleh bahwa nilai $p$ Value $=0,000$ ( $p$ value $<0,05)$ dengan $\alpha=$ 0,05 , maka Ho ditolak sehingga ada hubungan frekuensi konsumsi makanan dengan status gizi sampel di Kelurahan Belawan II Kecamatan Medan Belawan. Menurut asumsi peneliti untuk dapat menciptakan pola konsumsi makanan yang baik maka makanan yang disajikan harus bervariasi atau tidak membosankan, karena variasi makanan akan dapat meningkatkan selera makan anak balita sehingga kebutuhan nutrisi dalam tubuh terpenuhi. Kebutuhan bahan makanan perlu diatur supaya biasa diterima oleh anak balita dalam satu hari.

\section{KESIMPULAN DAN SARAN}

Tidak ada hubungan jumlah konsumsi makanan dengan status gizi anak balita di Kelurahan Belawan II Kecamatan Medan 
Belawan. Tidak ada hubungan jenis konsumsi makanan dengan status gizi anak balita di Kelurahan Belawan II Kecamatan Medan Belawan. Namun, ada hubungan frekuensi konsumsi makanan dengan status gizi anak balita di Kelurahan Belawan II Kecamatan Medan Belawan.

Disarankan kepada ibu dari anak balita sampel di Kelurahan Belawan II Kecamatan Medan Belawan agar diberi bekal pengetahuan dan keterampilan antara lain di Pos Yandu, terutama mengenai jenis dan frekuensi konsumsi makanan anak balita.

\section{REFERENSI}

1. Santoso, Soegeng dan Anne Lies Ranti (2004). Kesehatan dan Gizi. Jakarta : Rineka Cipta.

2. Arisman (2004). Gizi Daur Kehidupan. Jakarta : Buku Kedokteran EGC.

3. Waladow, Geiby, S. M. (Agustus 2013). Hubungan Pola Makan dengan Status Gizi Pada Anak Usia 3-5 tahun di wilayah Kerja Puskesmas Tompaso Kecamatan Tompaso. ejournal keperawatan (e-Kp), 16. Skripsi. Universitas Sam Ratulangi Manado.

4. Purwani, Erni dan Mariyam (2013). Pola Pemberian Makan dengan Status Gizi Anak Usia 1 sampai 5 Tahun di Kabunan Taman Pemalang.

$<$ http://jurnal.unimus.ac.id/index.php/JKA/ar ticle/view/903.pdf> [diakses pada 12 Januari 2016]

5. Supariasa, I Dewa Nyoman, Bachyar Bakri dan Ibnu Fajar (2001). Penilaian Status Gizi. Jakarta : Buku Kedokteran EGC.

6. Balitbang Kemenkes RI (2013). Riset Kesehatan Dasar 2013. $<$ http://www.depkes.go.id/resources/downlo ad/general/Hasil\%20Riskesdas\%202013.pd f> [diakses pada 17 Januari 2016]

7. Dinkes (2011). Profil Kesehatan Kota Medan 2011. Medan : Dinkes Kota Medan.

8. Waruwu, Mawwada Azizah Sari (2014). Pengaruh Bimbingan Penyusunan Menu Balita dengan Metode Ceramah dan Permainan terhadap Pengetahuan lbu di Kecamatan Medan Belawan. $<$ http://repository.usu.ac.id/bitstream/12345 $6789 / 42246 / 7 /$ Cover.pdf $>$ [diakses pada 7 Oktober 2015] 